\title{
Exercise induced asthma and endogenous opioids
}

\author{
RC GAILLARD, M BACHMAN, T ROCHAT, D EGGER, R DE HALLER, \\ AF JUNOD
}

From the Department of Medicine, University Hospital, Geneva, Switzerland

ABSTRACT Concentrations of endogenous opioid peptides in the plasma are increased during exercise and these substances have been implicated in the pathogenesis of asthma induced by chloro propamide and alcohol in diabetic patients. This work was undertaken to determine whether exercise induced asthma might be mediated by endogenous opioids. Plasma $\beta$ endorphin, met-enkephalin ${ }_{i}$ and adrenocorticotrophic hormone (ACTH) concentrations were measured in five asthmatic patients and five normal volunteers breathing cold air during exercise. In four of the patients the? effect of an infusion of naloxone on $\mathrm{FEV}_{1}$ was also measured during exercise induced asthma.Exercise produced acute bronchoconstriction in all asthmatics, characterised by a fall in FEV $F_{1}$ whereas no change occurred in normal subjects. There was no difference in plasma met-enkephalin, $\beta$ endorphin, and ACTH concentration between the two groups. Infusion of naloxone neither prevented nor worsened exercise induced asthma. These data suggest that endogenous opioids ${ }^{\circ}$ probably do not play a part in the development of exercise induced asthma.

Since their discovery ${ }^{1-2}$ endogenous opioids have been shown to play a part in both physiological and pathophysiological conditions. Their role in the response to chronic pain, ${ }^{3}$ in neuroendocrine regulation (for review see ref 4), and in narcotic dependence ${ }^{5}$ is well established. Their possible role in respiratory regulation is still under investigation. ${ }^{6}$

It has recently been reported that endogenous peptides with opiate like activity, such as enkephalin, may mediate the asthma and facial flush observed in some diabetics treated with chlorpropamide when they drink alcohol. ${ }^{7}$ Both sodium cromoglycate and the specific opiate antagonist were able to prevent the asthmatic reaction, which could be reproduced by an enkephalin analogue with opiate like activity. ${ }^{8}$ It is also known that various types of exercise increase plasma concentrations of endogenous opioids such as $\beta$ endorphin..$^{9-11}$ The present study was therefore undertaken to investigate whether exercise induced asthma might also be related either to an increase in circulating opioid peptide- $\beta$ endorphin or metenkephalin or both-or to increased sensitivity to endogenous opiates, or to both. For this purpose plasma $\beta$ endorphin and met-enkephalin immunoreactivities were measured in asthmatic patients

Address for reprint requests: Dr RC Gaillard, Clinique médicale, Hôpital cantonal universitaire, 1211 Geneva 4, Switzerland.

Accepted 23 October 1985 breathing cold, dry air during exercise. In four of these asthmatic subjects the effect of naloxone perfusion of the respiratory variables during exercise induced asthma was also measured.

\section{Methods}

SUBJECTS AND PROTOCOL

Five patients suffering from exercise induced asthm $\frac{0}{\infty}$ and five healthy subjects (three men and two womeg in both cases) were studied. The subjects of the twa groups did not differ in age, weight, or body surfaco area. The mean ages of the asthmatic and contros subjects respectively were 29.2(SE 4.2) and 30.3(2.8d years, and the mean weights $65(4.7)$ and $67.2(3.6) \mathrm{kg}$. The mean body surface area was $1.72(0.1) \mathrm{m}^{2}$ for the asthmatic patients and $1.82(0.6) \mathrm{m}^{2}$ for the controf subjects. The patients were not receiving local or syso temic corticosteroid treatment. The controls had not smoked or taken any medication or alcohol for at least 24 hours before the experiment.

The study protocol was approved by the ethical committee of the Department of Medicine, University Hospital of Geneva. Each subject (patients and now mal volunteers) gave his written informed consent before starting the study.

Three days before the experiment a preliminary test determined the work load required to raise the heaf rate to at least $80 \%$ of the predicted maximum. ${ }^{12}$ The experiments were all performed between 8 and 10 ane 
After insertion of a cubital intravenous catheter the subjects were allowed to relax for at least $\mathbf{4 5}$ minutes. Forced expiratory manoeuvres were performed 15 minutes and immediately before the exercise as well as $0,5,10,15,20$, and 30 minutes afterwards. The forced expiratory volume for one second $\left(\mathrm{FEV}_{1}\right)$ was measured with a Fleisch pneumotachograph, connected to an $8805 \mathrm{~B}$ amplifier, and a Hewlett-Packard integrator 88 and recorded on a recorder. The best $\mathrm{FEV}_{1}$ out of two or three forced expirations was selected. The challenge consisted of 10 minutes of exercise on a bicycle ergometer. During the first two to four minutes the work load was increased stepwise to reach a stable level for the last six minutes. Throughout the test the subjects breathed through a mouthpiece and received dry, cool air generated by an apparatus similar to that described by Strauss et al. ${ }^{12}$

Twenty five millilitre blood samples were collected in chilled heparinised tubes at various times before and after the exercise. The tubes were immediately spun down at $4^{\circ} \mathrm{C}$ and the plasma was flash frozen and stored at $-20^{\circ} \mathrm{C}$ until assayed.

\section{NALOXONE INFUSION}

The effect of naloxone was studied in four of the asthmatics (two men and two women). The protocol was as described above, except that the subjects received, in random order and double blind fashion, two infusions, with a minimum interval of one week between them-namely naloxone $(0.4 \mathrm{mg} / \mathrm{min})$ and saline, infused by micropump through an indwelling venous cannula. The infusion was started five minutes before the beginning of the exercise test and continued for 20 minutes afterwards. Cardiorespiratory variables were measured as described above but no blood samples were taken. The protocol was performed twice on three of the patients and once on the fourth.

\section{RADIOIMMUNOASSAYS}

Plasma adrenocorticotrophic hormone (ACTH), $\beta$ endorphin ( $\mathrm{COOH}$ terminal $\beta$ lipotrophin), and metenkephalin were measured by radioimmunoassay after extraction. ${ }^{13-15}$ The $\beta$ endorphin assay used an antiserum showing equimolar cross reactivity with $\beta$ lipotrophin. Met-enkephalin was assayed by oxidising the samples with $\mathrm{H}_{2} \mathrm{O}_{2}$ after extraction and using an antiserum with high specificity for met-enkephalin sulphoxide. ${ }^{15}$ The met-enkephalin antiserum had unique specificity with no cross reaction with leuenkephalin, purified human $\beta$ endorphin, $\beta$ lipotrophin, or a large number of other hypothalamic, pituitary, and gastrointestinal peptides. ${ }^{15}$ The limits of detection of these assays for plasma measurements were 8,15 , and $2.5 \mathrm{pg} / \mathrm{ml}$ for ACTH, $\beta$ endorphin, and met-enkephalin respectively and the mean extraction rates for these peptides were $63 \%, 75 \%$, and $29 \%$.

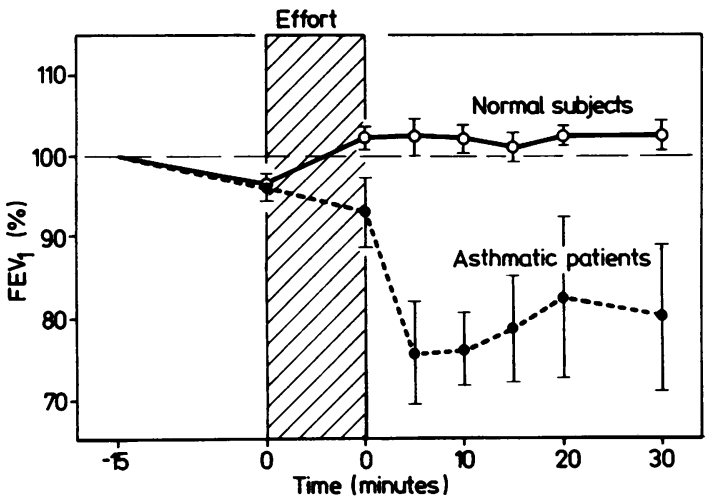

Fig 1 Percentage change (means and standard errors) in $F E V_{1}$ in response to 10 minutes of exercise (shaded area) in normal subjects and asthmatic patients. (Baseline values taken as $100 \%$ ).

The intra-assay coefficients of variation for the ACTH and $\beta$ endorphin assays were less than $8 \%$, and less than $9 \%$ for met-enkephalin. The inter-assay coefficients of variation were respectively $15 \%$ and $12 \%$.

\section{STA TISTICS}

The statistical methods used were analysis of variance for repeated measurements to analyse the change in opioid levels as a function of time, and the MannWhitney rank test to compare differences between two groups. All results are expressed as means with standard errors in parentheses.

\section{Results}

During the last six minutes of exercise the temperature of the inspired air and the ventilation volume per

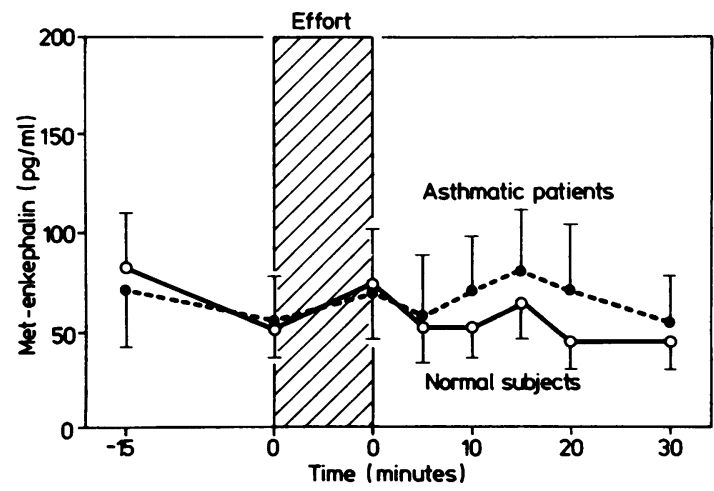

Fig 2 Plasma met-enkephalin concentrations (means and standard errors) in response to 10 minutes of exercise (shaded area) in normal subjects and asthmatic patients. 


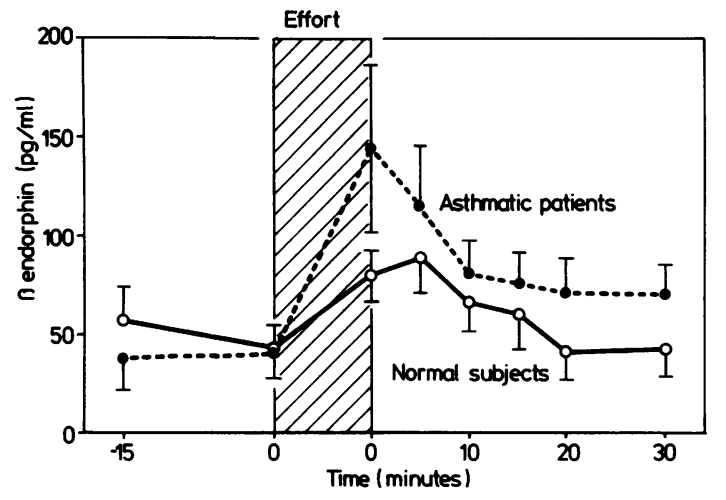

Fig 3 Plasma $\beta$ endorphin concentrations (means and standard errors) in response to 10 minutes of exercise (shaded area) in normal subjects and asthmatic patients.

minute (in relation to body surface area) was similar in the asthmatic and the control subjects (unpaired $t$ test). The values were respectively $-11.2^{\circ}\left(1^{\circ}\right) \mathrm{C}$ and $39.1(2.8) 1 \mathrm{~min}^{-1} \mathrm{~min}^{-2}$ in the asthmatics and $-9.9^{\circ}\left(0.9^{\circ}\right) \mathrm{C}$ and $38.2(4) 1 \mathrm{~min}^{-1} \mathrm{~min}^{-2}$ in the control subjects. Heart rates when expressed as percentages of predicted maximal heart rate were similar in the two groups (92(3) in the asthmatic and 95(2) in the control subjects).

In asthmatics $\mathrm{FEV}_{1}$ decreased within 10 minutes of the exercise to $32-82 \%$ of the basal value obtained 15 minutes before the exercise. In control subjects FEV did not change significantly, varying after exercise from $94 \%$ to $107 \%$ of the basal value (fig 1 ).

Plasma met-enkephalin concentration did not change significantly during the experiment and there was no difference between the normal subjects and the

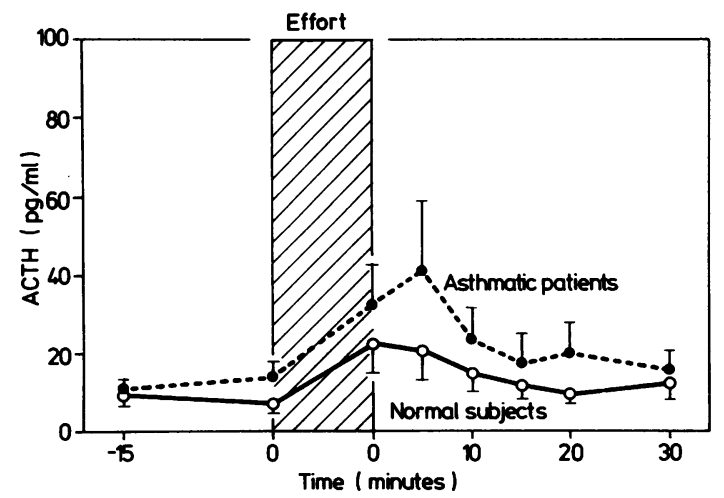

Fig 4 Plasma adrenocorticotrophic hormone (ACTH) concentrations (means and standard errors) in response to 10 minutes of exercise (shaded area) in normal subjects and asthmatic patients.
Postexercise percentage change in FEV $V_{1}$ after administration of placebo and naloxone

\begin{tabular}{|c|c|c|c|}
\hline Subject No & Test & Placebo & Naloxone \\
\hline 1 & I & $\begin{array}{l}-15 \\
-20\end{array}$ & $\begin{array}{r}-9 \\
-13\end{array}$ \\
\hline 2 & I & $\begin{array}{l}-10 \\
-11\end{array}$ & $\begin{array}{r}-17 \\
-9\end{array}$ \\
\hline 3 & I & $\begin{array}{l}-59 \\
-66\end{array}$ & $\begin{array}{l}-45 \\
-\end{array}$ \\
\hline 4 & I & -6 & -12 \\
\hline
\end{tabular}

asthmatic patients (fig 2). Plasma $\beta$ endorphin concen $\overrightarrow{\vec{\alpha}}$ tration on the other hand increased significantly at the end of the work test in both groups $(\mathrm{p}<0.02)$ (fig 3$)_{\mathrm{H}}$ The maximal percentage increment above basdif values was $106 \%$ in the control group and $249 \%$ in the asthmatic patients group. This difference if increments was not significant $(p=0.1428$, MannWhitney rank sum test). Plasma $B$ endorphin concen trations returned to the basal values earlier in the controls than in the asthmatic subjects. Plasmer ACTH concentrations in both groups showed pattern similar to that of $\beta$ endorphin (fig 4).

There was no correlation between the heart rate a the end of the exercise and the increase in $\beta$ endorphi levels after the exercise.

\section{NALOXONE INFUSION}

In patients 1 and 2 the protocol consisting of naloxon and saline infusions in random order was repeated twice. Another asthmatic (patient 3) performed the test twice with saline and only once with the naloxone infusion. At the beginning of the second test wit naloxone he felt unwell while exercising and we had th stop the experiment. The fourth patient had only one saline and one naloxone infusion, which was followed. by generalized urticaria, starting 12 hours after the infusion, lasting for 36 hours, and requiring trea ment. As shown in the table, there was no significant difference in the decrease in $\mathrm{FEV}_{1}$ between subjects receiving saline and those receiving naloxone.

\section{Discussion}

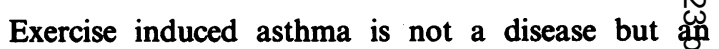
expression of bronchial hyperreactivity where the nature of the challenge is exercise. Since the occurrence of exercise induced asthma is clearly associatod with hyperventilation in an environment of dry, coof air, ${ }^{16}$ we used exercise or a cycle ergometer associated with a dry, cold air generator. This type of challenge has been shown to be the most potent and reproducible means of producing exercise induced asthma. ${ }^{1718}$ When exposed to this test the asthmatic 
subjects, as expected, developed acute bronchoconstriction, characterised by a fall in the FEV ${ }_{1}$, whereas the normal subjects showed no change. Despite this striking difference in airway response, there was no significant difference in plasma metenkephalin, $\beta$ endorphin, or ACTH concentrations between the two groups.

The absence of significant differences in $\beta$ endorphin and met-enkephalin plasma concentrations between normal subjects and asthmatic patients appears to rule out these circulating opioids as a cause of exercise induced asthma. The increase in $\beta$ endorphin, which was sustained slightly longer in the asthmatic group, might be related to the more severe stress resulting from bronchoconstriction. The absence of a similar stress response in met-enkephalin concentrations is not surprising since this peptide is not affected by stresses such as surgery and insulin induced hypoglycaemia. ${ }^{19}$ On the other hand, since plasma met-enkephalin has a short half life, possibly an increase in the plasma concentration of this peptide could be missed at the periphery. A rise in plasma met-enkephalin concentrations, however, is unlikely to have been missed through insensitivity of the radioimmunoassay. Indeed, in three recent studies using the same met-enkephalin assay with the same characteristics we and others were able to show increases in plasma met-enkephalin concentrations in chronic renal failure, exercise, and acupuncture ${ }^{19-21}$ The absence of changes in opioid concentrations in the peripheral circulation does not, of course, rule out their local release and a role in exercise induced asthma. Two main theories have been proposed to explain the bronchoconstriction associated with hyperventilation and airway cooling in asthmatic patients. One attributes a predominant role to the vagus nerve $e^{22-23}$ whereas the other emphasises the part played by mediator substances released from mast cells in the airways. ${ }^{1724}$ Opioid peptides are known to be present in several neural pathways. They could function as neurotransmitters or neuromodulators or act locally as hormones. A role for these peptides might thus be compatible with either theory, for they could modulate either the effect of the vagus nerve or the release of mediators from the mast cells.

To test this hypothesis, we decided to block the possible opioid effects by infusing the specific opiate antagonist naloxone. The dose of naloxone chosen was similar to that previously reported to block the induction of asthma by chlorpropamide and by alcohol and to reverse the asthma induced by an enkephalin analogue. ${ }^{7}$ We therefore postulated that this dose should suffice to block both the naloxone sensitive $\mu$ and the naloxone insensitive $\delta$ receptors. Even at this high dose, however, naloxone neither blocked nor worsened exercise induced asthma. These results do not appear to support the hypothesis that such asthma is mediated by a local effect of opioid peptides, whether they act as neurotransmitters or as local hormones. We recognise that the number of subjects tested with naloxone was small and does not therefore preclude the existence of subgroups with different responses. The occurrence of undesirable side effects in two out of four patients prevented us from extending the study.

Although investigation of the effect of exercise on endogenous opioids was not the purpose of this study, we observed a significant rise in $\beta$ endorphin and ACTH concentrations after the exercise test but only a variable and non-significant effect on metenkephalin concentrations. The rise of the two peptides ACTH and $\beta$ endorphin, derived from the common precursor pro-opiomelanocortin, ${ }^{25}$ has already been reported by others ${ }^{9-11}$ after physical exercise. On the other hand, the absence of significant changes in met-enkephalin concentration was surprising, since exercise is associated with adrenal catecholamine secretion and met-enkephalin is cosequestered with catecholamines in the chromaffin granules of the adrenal medulla. A recent study, however, reports a significant rise in plasma met-enkephalin concentrations after one hour of treadmill exercise, although the response also showed considerable heterogeneity. ${ }^{20}$ Perhaps therefore our exercise test was either too short or not strenuous enough to produce increase in this peptide at the peripheral level.

We are greatly indebted to Professor LH Rees and Dr V Clement-Jones (St Bartholomew's Hospital, London) for the gift of $\beta$ endorphin and met-enkephalin antibodies and tracers, to Professor AF Muller (Clinique Médicale, Geneva) for support, to Mrs D Turnill and MC Jacquier for technical assistance, and Mrs C Todisco for skilled preparation of the manuscript. This work was supported by the Swiss National Science Foundation (grant 3.814.084).

\section{References}

1 Hughes J, Smith TW, Kosterlitz HW, Fothergill LA, Morgon RA, Morris AR. Identification of two related pentapeptides from the brain with potent opiate agonist activity. Nature 1975;248:577-9.

2 Bradbury AF, Smyth DG, Snell CR, Birsdall NJM, Hulme EC. C-Fragment of lipotropin has high affinity for brain opiate receptors. Nature 1976;260:793-5.

3 Clement-Jones V, McLoughlin L, Tomlin S, Besser GM, Rees LH, Wen HL. Increased $\beta$-endorphin but not metenkephalin levels in human cerebrospinal fluid after acupuncture for recurrent pain. Lancet 1980;ii:946-9.

4 Grossman A, Rees LH. The neuroendocrinology of opioid peptides. Br Med Bull 1983;39:83-8. 
5 Clement-Jones V, McLoughlin L, Lowry PJ, Besser GM, Rees LH, Wen HL. Acupuncture in heroin addicts: changes in met-enkephalin and $\beta$-endorphin in blood and cerebrospinal fluid. Lancet $1979 ;$;i: $380-3$.

6 McQueen DS. Opioid peptide interactions with respiratory and circulatory systems. Br Med Bull 1983;39:77-82.

7 Leslie RDG, Bellamy D, Pyke DA. Asthma induced by enkephalin. Br Med J 1980;280:16-8.

8 Fraioli F, Moretti C, Paolucci D, Alicicco E, Crescenzi F, Fortunio G. Physical exercise stimulates marked concomitant increase of $\beta$-endorphin and adrenocorticotropic hormone (ACTH) in peripheral blood in man. Experientia 1980;36:987-9.

9 Colt EWD, Wordlaw SL, Frantz AG. The effect of running on plasma $\beta$-endorphin. Life Sci 1981;28:1637-40.

10 Can DB, Bullen BA, Skrinar GS, et al. Physical conditioning facilitaters the exercise-induced secretion of $\beta$-endorphin and $\beta$-lipotropin in women. $N$ Engl J Med 1981;305:560-3.

11 Burskirk ER. Science and medicine of exercise and sports. 2nd ed. New York: Harper and Row, 1974:125.

12 Strauss RH, McFadden JR, Ingram RH, Chandler EC, Deel JR, Jaeger JJ. Influence of heart and humidity on the air way obstruction induced by exercise in asthma. $J$ Clin Invest 1978;61:433-40.

13 Rees LH, Cook DM, Kendall JW, et al. A radioimmunoassay for rat plasma ACTH. Endocrinology 1971;89:254-61.

14 Jeffcoate WJ, Rees LH, Lowry PJ, Hope J, Besser GM. $\beta$-endorphin in human cerebrospinal fluid. Lancet 1978;ii:119-21.

15 Clement-Jones LV, Lowry RJ, Rees LH, Besser GM. Development of a specific extracted radioimmunoassay for methionine enkephalin in human plasma and cere- brospinal fluid. J Endocrinol 1980;86:231-43.

16 Strauss RH, McFadden ER, Ingram RH, Jaegger JJ: Enhancement of exercise-induced asthma by cold air N Engl J Med 1977;297:743-7.

17 Deal EC, McFadden ER, Ingram RH, Jaegger JJC Hyperpnea and heat flux: initial reaction sequence if exercise-induced asthma. J Appl Physiol 1979;46:476-83.

18 Kilham H, Tooley M, Silverman M. Running, walking and hyperventilation causing asthma in children. Thora 1979;34:582-6.

19 Smith R, Grossman A, Gaillard R, et al. Studies on circu $\overrightarrow{0}$ lating met-enkaphalin and renal and adrenal disease. CliinEndocrinol 1981;15:291-300.

20 Howlett TA, Tomlin S, Ngahfoong L, et al. Release of $\beta$-endorphin and met-enkephalin during exercise iक्षे normal women: response to training. $\mathrm{Br} \mathrm{Med}$ 1984;288:1950-2.

21 Kiser RS, Khatami M, Gatchel RJ, et al. Acupuncturèr relief of chronic pain syndrome correlates with increasedu plasma met-enkephalin concentrations. Lancet 1983;i⿱ 1394-6.

22 Zeballos RJ, Shturman-Ellstein R, McNally JF, Hirsch $\mathrm{JE}$, Souhrada JF. The role of hyperventilation in exercise-induced bronchoconstriction. Am Rev Respi产 Dis 1978;118:877-84

23 Gold WM, Kessler GF, Yu DYC. Role of vagus nerve $\overrightarrow{50}$ in experimental asthma in allergic dogs. $J$ Appl Physiog 1972;33:719-25.

24 Deal EC, McFadden ER, Ingram RH, Jaegger JJ. Effect8 of atropine on potentiation of exercise-induced bronchos spasm by cold air. J Appl Physiol 1978;45:238-43.

25 Mains RE, Eipper BA, Ling N. Common precursor tô corticotropins and endorphins. Proc Natl Acad Sci US 1977;197:3014-8. 